\title{
THE EFFECT OF DIVERSIFICATION STRATEGY ON ORGANIZATIONAL PERFORMANCE
}

\section{- Moruff Sanjo Oladimeji, Itohowo Udosen}

\begin{abstract}
In today's dynamic and turbulent business environment, diversification has become a catalyst for achieving competitive advantages and the creation of synergy in market operations. This is because manufacturing companies operate in a highly competitive environment, especially among firmsthat produce the same or similar goods. This study examines the effect of a diversification strategy on an organization's performance in the manufacturing sector. A quasi-experimental study with an ex-post facto research design were used for the study. The respondent populationconsists of thirty-one organizations listed in Nigerian Stock Exchange (NSE) for a period of 20 years (1997-2017), while the sample size is comprised of six organizations purposively selected based on their life-span and level of diversification. Three hypotheses were formulated and tested using ratio analysis, while performance was measured in terms of ROA, ROI and ROE; organization size, organizationvalue and growth; as well asleverage and liquidity. Data was drawn from the financial reports of the selected organizations, with E-View version 9 used for the data analysis. The study revealed that diversified organizations outperformundiversified ones in terms of ROA and ROI. While related diversified organizations were discovered to be positive in terms of ROA $(26.8 \%)$, unrelated and hybrid diversified organizations were positive in $\operatorname{ROE}(81.7 \%$ and $20.5 \%)$. A diversification strategy leads to growth and profitability $(20 \%)$ and a strong capital structure to cover liabilities $(26 \%)$. The study concluded that diversification is a strategic tool for achieving strategic relevance and spontaneous performance.
\end{abstract}

Keywords: diversification strategy, performance, organization, profitability, competitive advantage JEL classification: L1, L25

Received: May, 2019

1st Revision: October, 2019

Accepted: October, 2019

\section{INTRODUCTION}

The effect of a diversification strategy on performance has over the decades attracted the attention of scholars in the field of management and social sciences. Nonetheless, the justificationsfor diversification as well as results vary, with some findings found to be inconclusive (Asrarhaghighiet al., 2013). Organizations may choose to diversify to survive the dynamics of business environment (Nyangiri \& Ogollah, 2015); for expansion (Su \& Tsang, 2015); increase profitabil- 
ity (Karimi, 2013; Yigit \& Tur, 2012); foster efficiency in the use of resources and create investment opportunities (Emel \& Yildirim, 2016; Hasby et al., 2017); to achieve economies of scale to exploremarket options and opportunities (Sindhu et al., 2014); and as a turnaround strategy (Harrigan, 2012). Krivikapic et al. (2017) conclude that organizations diversify in order to have a better position in the market, while Akewushola (2015) opined that a diversification strategy enablesan organization to expend its excess resources for economic use. However, subsequent studies have revealed contradictory results, some negative and others finding no relationship among variables (Shyu \& Chen, 2009). Diversification does not necessarily lead to improved performance and not all diversified organizations are profitable (Manyuru et al., 2017; Nasiru et al., 2011; Jasper, 2016). Also, an increased diversity within a business portfolio may result in a loss of control by top executives, which also deteriorates business performance (Yigit\& Tur, 2012; Uguwany \& Ugwu, 2013). Schommer et al. (2019) foundthat the performance of diversified organizations declines with time, and decision makers whoform diversification strategies find it increasingly difficult over time to avoid retrogressive performance.

The increasing demand for product varieties by consumers and theircontinuous substitution has forced organizations to come up with strategies on how to improve performance. Irrespective of opportunities in the business environment, organizations face threats that distort their performance, hence increase the difficulty of survival. This study, therefore, examines the effect of a diversification strategy on performance within themanufacturing sector in Nigeria with these specific objectives:

1. determine the significant variance among related, unrelated and hybrid diversification using the ROA, ROE and ROI measures of performance.

2. examine the significant variance among related, unrelated and hybrid diversification strategies in terms ofsize, value and growth.

3. access the significant variances between leverage and liquidity in terms ofrelated, unrelated and hybrid diversification.

The study was divided into five sections, with section one introducing the subject matter, section two presenting a literature review, section three the research methodology employed for the study, section four the research findings and discussion of the findings, and section five provides the conclusion and recommendations of the study. The study was limited to six manufacturing companies out of the thirty-three companies listed in the Nigeria stock exchange.

\section{THEORETICAL BACKGROUND}

Diversification has become a popular survival strategy among organizations in an effort to outpace competitors (Haug \& Ultich, 2013). Whether in related form or not, diversification is a strategic option used by more and more managers to improve performance (Castaldi \& Giarratana, 2018; Makau\&Ambose, 2018). Organizations havechosen from among several available strategic alternatives to make the best use of the available resources to reach predetermined goal sregarding increased performance (Rowe, 2014; Xaxx, 2017).

Diversification is undertakenwhen an organization aims at changing its business definition either by developing new products or expanding into a new market individually or jointly with 
another entity (Su \& Tsang, 2015). It is a catalyst for competitive advantage and a means whereby an organization spreads its risk across several businesses to increase profitability, reduce the risk of bankruptcy, create synergy, enhance market operations and improve performance (Oladele, 2012). A diversification strategy helps in improving debt capacity, asset deployment and further allows the organization to use its existing skills, expertise and competences to produce unique products (Ajayi \& Madhumati, 2012; Pandya \& Rao, 2011; Junior \& Funchai, 2013). Diversified organizations can effectively pool unsystematic risk in order to reduce the viability of operating cash flow to enjoy competitive advantages (Dosi \& Teece, 1993). Nevertheless, diversification should not be seen as a panaceathat will meet every single one of the various challenges faced by organizations in today's dynamic business environment.

Zheng-fend \& Lingyan (2012) as well as Oladele (2012) have shown howorganizations are exposed to huge risks and structural challenges that can stunt managerial decisionsregardingwhether to spin-off aspects of operationsor to become part of aholding group structure. In addition, Ugwuany \& Ugwu (2013) have affirmed that diversification can bevalue-destroying and usually leads to discount as a result of agency problems between managers and shareholders and those averse to taking on managerial risk. It may also result in the weakening of corporate governance structure and family relationships (Alli et al., 2016). Consequently, if not properly planned and implemented, diversification may lead to retrogressive performance, especially in less developed countries such as Nigeria which are plagued with instability, economic uncertainty, incessant shut-downs of economic activities, a lack of technology and resources, as well as deteriorating infrastructure (Haim, 2015; Thompson \& Stickland, 2003). Sahu (2017) has concluded that diversification is not a very efficientstrategy to increase an organization's profit and may result inpoor performance, while higher diversification is retrogressive in terms of overall performance. Santarelli \& Tran (2016) have presentsimilar opinions regarding these variables.

\subsection{Theoretical framework}

Two theories, Modern Portfolio Theory by Henry Markowitz and the Resource-based view by Birger Wernerfelt, are germane to the present study, which is based on aptitude in the explanation of the dependent and independent variables.

Modern Portfolio Theory (MPT) was introduced to assist in the selection and formation of the most efficient diversified portfolio in order to most greatly reduce risk. MPTis a tool that guides investors on the expected risk and returns associated with investments. At the most basic level, the theory recommendsthat investors should invest in several portfolios rather than rely on a single portfolio, by which investors can reap the benefits of diversification through reduced risk by spreading it among portfolios.

Resource-based theory (RBT) allows an organization to leverage upon its inward capabilities which are rare and inimitable to achieve competitive edge over other organizations. The theory states that all organizations have in their possession several untapped resources with potential that makes them superior over competitors and also enables increased performance when properly combined. 


\subsection{Empirical reviews of the use of a diversification strategy and organization of performance}

In the study on the effect of a diversification strategy on organizations' performance, using panel dataset of 68 European retailers from 19 countries between 1997 and 2010; Oh et al. (2014) affirmed that both inter-regional and intra-regional diversification havehorizontal S-curve relationship with performance. However, a subsequent study by Hashai (2015) linked within industry adjustment cost and coordination cost as reasons for the S-Curve. Valis-Boas \& Gonzelaz (2015) using Entropy, Tobin-q and Herfindahl indexes highlighted that the S-curve seems appropriate in the measure of diversification and performance because diversification is negatively linked to performance due to organizations' inability to transfer knowledge, negotiable contracts and handle institutional practices in host countries. Moreover, international diversification was deemed harmful to performance.

Zheng-Feng \& Lingyan (2012) used 3050 organizations from COMPUSTAT using the Tobinq equation and Standard Industrial Classification code to disclose that organizations' decision to diversify depends on the interaction of two effects - economies of scale and agent problems where diversification get smaller once the organization engages in more than 3 industries. However, Keng (2010) opined that companies with numerous portfolios have greater advantage over single industries. Castaldi \& Giarratana (2018) studied diversification on the performance of professional service firms using US-based management consulting firms from 2000 to 2009. The panel regression results showed that diversification is advantageous to professional service firms while performance is positively related to the strategy used by specialized barrow brands.

LaRocca \& Stagliano (2012) examined the effect of unrelated diversification on performance using 2,613 organizations in Italy from 1980 to 2007. To avoid unobservable organizations' heterogeneity, three economic methods, fixed-effect estimator, instrument variable estimator, and Hecman, were used for the study. It was revealed that the benefits of diversification outweighs its cost. Also in US, Akkermans (2010) conducted a study using 354 organizations listed in the US Standard and Poor 500 Index data span from 2005-2006 and 2008-2009. Using multiple regression to test the hypothesis, the study revealed that diversification is less positively associated with performance and the benefits associated with unrelated diversification are harder to makeduring periods of crisis.

Gul (2011) examined the effect of integrated strategies on performance, using 147 manufacturing organizations in Denmark. Entropy and Herfindahl Indexes were used to measure diversification. The study revealed that manufacturing industries have the highest average performance measure and related integrated companies outperform unrelated diversified organization. Martinez-Campilo (2016) built on agency-stewardship approach to examine the benefits of related and unrelated diversification strategies on leadership style, using 183 firms in Spain. The result highlighted that the relevance of leadership style has a positive impact on the profitability and growth of diversified firms.

Makau \& Ambrose (2017) examined the impact of portfolio diversification on financial performance of investment organizations listed in Nairobian Stock Exchange, Kenya. Explanatory non-experimental research design was used for the study with the conclusion that diversification 
strategy remains a universal research phenomenon for researchers in the field of management and social science since the resultant effect remains inconclusive. Manyuru et al. (2017) conducted a study on 38 companies listed in NSE, Kenya. The study concluded that managers need to be courteous in pursuing diversification because the cost outweighs the benefits. Nyaingiri \& Ogollah (2015) studied Semeer Group using experimental research design. It was indicated that the general economic environment, organizations' characteristics and co-insurance affect the performance of diversified firms in Kenya.

Santarelli\& Tran (2016) conducted a study in Vietnam on firm's profitability and diversification activities. The study showed that diversification has a curvilinear effect on profitability but with an associated decline in performance. Rishi, Rudra and Vinay (2014) took a sample of 44 companies in India sing Tobin-q, Ulton and Entropy Indexes to measure diversification. The result showed that companies involved in the product diversification are more profitable and increase their tangible assets when compared to undiversified firms. However, Sahu (2017) stated that diversification though profitable does not necessarily lead to improvement in performance.

Sindu et al. (2014) examined 20 diversified and 20 undiversified firms in Pakistan. The study revealed no multi-collinearity between diversified and undiversified firms since diversified firms are risky. Quershi et al. (2012) showed that diversified organisations are more profitable compared to the undiversified ones. However, Weirsmer \& Beck (2017) disputed the credibility of the subjective grouping organizations as diversified without clarity on the degree and extend of diversification. Krivokapic et al. (2017) sampled 23 industries using Entropy and Hausman test to determine the relationship between diversification and performance of insurance companies in Siberia. The study showed that diversified insurance companies outsmart the undiversified ones. Ivan\& Maja (2010) stated otherwise.

Diversification is fundamental to the success of organization in the face of downturn. To determine the effect of diversification on performance, Akewushola (2015) studied 13 selected ICT firms, concluding that the performance impact of related market diversification is not the same for all organizations and it is largely relative and moderated by the intensity of the ICT usage within organizations. Ayeni (2013) predicted the effects of economic diversification on the development of tourism in Nigeria. The study revealed the positive roles of tourism in development. It concluded that Nigerian economy wouldbe prosperous if it diversified into tourism.

In a study on marketing capabilities and diversification on performance of product manufacturing organizations based in Lagos State, Sulaimon et al. (2015) revealed that a significant relationship exists between market capabilities and organizations' performance while diversification has asignificantly strong impact on performance..Ugwuanyi \& Ugwu (2012) sampled 18 banks suing expose-facto research design. The study discovered that diversified banks can pool their internally generated funds and resources to create financial synergy to ensure growth. This corresponds with the Modern portfolio theory since organizations can identify their rare capabilities or channel their resources to produce economic good.

Oyedijo (2012) took a sample of 48 companies made up of 15 specialized, 11 related, 14 unrelated and 8 mixed diversified organizations to study the effect of product-market diversification strategy on corporate financial performance. Nigerian organizations seeking sustainable fast 
growth and superior performance should pursue related product-market diversification strategy or specialized strategy or both. Oladele (2012) using manufacturing companies listed in Nigerian Stock Exchange revealed that an inverse relationship exists between diversification strategy and performance due to shareholders' influence.

\section{RESEARCH OBJECTIVE, METHODOLOGY AND DATA}

The study used ex-post facto research design with the study population of thirty-three (33) manufacturing companies listed in Nigerian Stock Exchange (December 2017). Purposive sampling technique was applied in the selection of 6 (six) companies based on their level of diversification whether related or mixed, and lifespan. The companies are Nestle, Unilever, Cadbury, Mayer \& Baker, Lafarge and Honeywell. The data were drawn from the annual reportsof the companiesfor a period of 20 years (1993-2018). A ratio analysis was used to establish the variance among the variables, while allvariables were tested using performance indicators.

Based on the aforementioned objectives, the following research hypotheses were stated:

$\mathrm{H}_{\mathrm{o} 1}$ : There is no significant variance among related, unrelated and hybrid diversification using the ROA, ROE and ROI measures of performance.

$\mathrm{H}_{\mathrm{o} 2}$ : There is no significant variance among related, unrelated and hybrid diversification strategies in terms ofsize, value and growth.

$\mathrm{H}_{\mathrm{o} 3}$ : There is no significant variance betweenleverage and liquidity in terms ofrelated, unrelated and hybrid diversification.

\subsection{Analysis of Variables}

Tab. 1 - Descriptive Statistics of the Variables. Source: own research

\begin{tabular}{|l|l|l|l|l|l|l|l|l|}
\hline & OrgSIZ & OrgVAL & GRW & LEV & LIQ & ROA & ROE & ROI \\
\hline Mean & 15.9302 & 95.4942 & 20.9356 & 26.3374 & 19.48561 & 14.3278 & 34.6920 & 6.46803 \\
\hline Median & 15.9052 & 80.1762 & 18.0799 & 11.4041 & 11.68823 & 11.3450 & 22.6728 & 4.13546 \\
\hline Max. & 22.1992 & 332.434 & 22.42882 & 74.3122 & 12.81130 & 15.3369 & 33.9455 & 73.5798 \\
\hline Min. & 7.4373 & 0.0228 & -11.9144 & -4.6663 & 0.066174 & -22.6595 & -21.026 & -12.181 \\
\hline Std. Dev. & 2.0867 & 72.8602 & 19.9606 & 10.5966 & 26.52504 & 13.6494 & 30.5970 & 65.7071 \\
\hline Skewness & -1.0534 & 1.2866 & 11.0771 & 4.8398 & 3.077717 & 11.0772 & 10.6777 & 10.9840 \\
\hline Kurtosis & 7.3680 & 4.5450 & 1.238051 & 2.67619 & 11.47017 & 12.3806 & 11.7329 & 12.2405 \\
\hline Obs & 126 & 126 & 126 & 126 & 126 & 126 & 126 & 126 \\
\hline
\end{tabular}

Table 1 presents the descriptive statistics for all the organizationssampled to ascertain the appropriateness of the data collected from the financial reports. The table reveals that the measures of performance were all positive (ROA, ROE and ROI).This suggests that over time all the organizations sampled were experiencing high returns on assets, equity and investment. 


\section{RESULTS AND DISCUSSION}

Tab. 2 - Comparison of ROA, ROE and ROI of Related, Unrelated and Hybrid Diversifications. Source: own research

\begin{tabular}{|c|c|c|c|c|c|c|c|c|c|}
\hline & \multicolumn{3}{|l|}{ Related } & \multicolumn{3}{|c|}{ Unrelated } & \multicolumn{3}{|l|}{ Hybrid } \\
\hline & Average & $\begin{array}{l}\text { Std. } \\
\text { Dev }\end{array}$ & $\mathrm{CoV}$ & $\begin{array}{l}\text { Aver- } \\
\text { age }\end{array}$ & $\begin{array}{l}\text { Std. } \\
\text { Dev }\end{array}$ & $\mathrm{CoV}$ & Average & $\begin{array}{l}\text { Std. } \\
\text { Dev }\end{array}$ & $\mathrm{CoV}$ \\
\hline $\mathrm{ROA}$ & 26.8190 & 19.2971 & 0.7185 & 10.258 & 9.86132 & 0.961 & 22.4211 & 0.1827 & 1.3461 \\
\hline ROE & 14.2235 & 71.5736 & 5.0320 & 20.579 & 50.2622 & 2.442 & 81.7116 & 52.3659 & 0.6408 \\
\hline ROI & 12.1520 & 92.9401 & 7.6481 & 12.738 & 12.7174 & 0.998 & 53.9034 & 68.2278 & 1.2657 \\
\hline
\end{tabular}

Table 2 presents a ratio analysis of performance indicators in measuring which of the diversification strategies enhances the organization's performance. Based onthe results, the average ROA of organizations that adopted a related diversification strategy is $26.8 \%$, which is higher than that of a hybrid diversification strategy $(22.4 \%)$ and unrelated diversification strategy $(10.2 \%)$. The average ROE of organizations that adopted a hybrid diversification strategy is $81.71 \%$, which is higher than that of a related diversification strategy $(14.22 \%)$ and unrelated diversification strategy $(20.58 \%)$. The average ROI of organizations that adopted a hybrid diversification strategy is $53.90 \%$, which is higher than that of a related diversification strategy $(12.15 \%)$ and unrelated diversification strategy $(12.72 \%)$.

ROA is more efficient, i.e. it uses related diversification as evidence from the leastcovariance value (0.71850) compared to other measures of performance such as ROE and ROI, which have a higher covariance of 5.0320 and 7.6481 respectively.

Similarly, ROA is more efficient when unrelated diversification is adopted. However, using hybrid diversification, the ROE with the leastcovariance value of 0.6408 is a more efficient measure of performance compared to other two measures.

Tab. 3 - Comparison of the Control Variables (Size, Value and Growth) for Related, Unrelated and Hybrid Diversification Strategies. Source: own research

\begin{tabular}{|l|l|l|l|l|l|l|l|l|l|}
\hline & \multicolumn{4}{|l|}{ Related } & \multicolumn{2}{l|}{ Unrelated } & \multicolumn{2}{l|}{ Hybrid } \\
\hline & $\begin{array}{l}\text { Aver- } \\
\text { age }\end{array}$ & $\begin{array}{l}\text { Std. } \\
\text { Dev }\end{array}$ & COV & $\begin{array}{l}\text { Aver- } \\
\text { age }\end{array}$ & $\begin{array}{l}\text { Std. } \\
\text { Dev }\end{array}$ & COV & $\begin{array}{l}\text { Aver- } \\
\text { age }\end{array}$ & $\begin{array}{l}\text { Std. } \\
\text { Dev }\end{array}$ & COV \\
\hline OrgSIZE & 16.8599 & 1.2580 & 0.074 & 14.464 & 1.3085 & 0.090 & 15.268 & 2.677 & 0.175 \\
\hline OrgVAL & 95.6706 & 54.2171 & 0.566 & 13.950 & 74.034 & 5.306 & 73.223 & 86.981 & 1.187 \\
\hline GRW & 39.1722 & 28.2211 & 0.720 & 14.160 & 12.254 & 0.865 & 35.142 & 42.306 & 1.203 \\
\hline
\end{tabular}

From Table 3, it can be seen thatthe organizations pursuing a diversification strategy have a higher size $(16.8 \%)$ in terms of total assets. This followsfrom the organizations' extension of existing resources and use of assets to produce more goods in the same line, a strategy which brings competition-enhancing opportunities for transferring valuable expertise, technological knowhow or other capabilities from one line of business to another. Hybrid diversified organizations fared well $(15.25 \%)$ compared to unrelated diversified organizations $(14.4 \%)$. 
Organisation size is more efficient using related diversification as evidence from the least covariance value (0.074) compared to other measures of performance such as organisation value and organisation growth with a higher covariance of 0.566 and 0.720 respectively.

Similarly, organization size is more efficient when unrelated and hybrid diversifications were adopted.

Tab. 4 - Comparison of Leverage and Liquidity in terms of Related, Unrelated and Hybrid Diversifications. Source: own research

\begin{tabular}{|l|l|l|l|l|l|l|l|l|l|}
\hline & \multicolumn{2}{|l|}{ Related } & \multicolumn{2}{l|}{ Unrelated } & \multicolumn{3}{l|}{ Hybrid } \\
\hline & $\begin{array}{l}\text { Aver- } \\
\text { age }\end{array}$ & $\begin{array}{l}\text { Std. } \\
\text { Dev }\end{array}$ & COV & $\begin{array}{l}\text { Aver- } \\
\text { age }\end{array}$ & $\begin{array}{l}\text { Std. } \\
\text { Dev }\end{array}$ & COV & $\begin{array}{l}\text { Aver- } \\
\text { age }\end{array}$ & $\begin{array}{l}\text { Std. } \\
\text { Dev }\end{array}$ & COV \\
\hline LEV & 21.379 & 10.867 & 0.508 & 49.789 & 40.820 & 0.819 & 46.694 & 12.478 & 0.267 \\
\hline LIQ & 11.670 & 43.271 & 3.707 & 27.559 & 28.153 & 1.021 & 27.171 & 39.272 & 1.445 \\
\hline
\end{tabular}

The leverage and liquidity positions of the sampled organizations revealed in Table 4 indicate that organizations pursing an unrelated diversification strategy are highly geared (49.7\%), while hybrid diversified organizations have about $46 \%$ debt in their capital structure andthe ones witha related strategy have a low gearing ratio $(21.3 \%)$. This suggests that organizations involved in the related diversification strategy have more equity in their capital structure and less debt, while unrelated diversified organizations have about $49 \%$ of their capital structure composed of debt.

Leverage is more efficient using related, unrelated and hybrid diversification as evidence from the leastcovariance values $0.508,0.819$ and 0.267 comparedto liquidity, with a higher covariance of $3.707,1.021$ and 1.445 respectively.

From the analysis, it was revealed that related diversifiedorganizations outperform unrelated and hybrid diversified organizations in terms of ROA and ROI through use of their capabilities and assets to attain a competitive advantage, whereas the hybrid diversified organizations generate higher returns in terms of ROEascompared to organizations using other diversification strategies. Hybrid diversified organizations have a higher risk return as comparedthose pursuing a related diversification and unrelated diversification strategy, which exhibited a high level of risk in terms of leverage and liquidity.

The study also showed that organization size is more efficient in the use of a related, unrelated and hybrid diversification strategyascompared to organization value and growth. Although thiswas in line with results from the study of Krivokapic et al. (2017), Qureshi et al. (2012) and Gul (2011), our study linked performance in terms of profit, market structure, and the level of concentration. Contradictingthese findings, Mohindru \& Chander (2010)as well as Akpinar \& Yigit (2016) found that organizations with the unrelated strategy outperform those with a related or hybrid strategy. While Ivan \& Maja (2010), Oladele (2012) and Adamu et al. (2011) ascertained that undiversified companies outperform highly diversified ones in terms of return on assets and profit margin, moderately diversified organizations were found to outperform highly diversified entitiesin terms of return on equity, return on asset and profit margin. 


\section{CONCLUSION}

It was observed that while diversified organizations outperform undiversified organizations in terms of profitability, market value and shareholder value, there were also periods when these organizations were experiencing dwindling performance since the ROI, ROE and liquidity were found to be unstable and unpredictable for a particularspecified period. Further, organizations pursuing related strategies perform better than unrelated and hybrid organizations. Nevertheless, organizations pursuing a hybrid strategy and unrelated strategy generate higher returns in ROE and ROI.The study concluded that the benefit of diversification outweighs the cost, thusdiversification hasa positiveeffect on an organization's performance.

Based on these findings, it is recommendedthat organizations that wishto achieve economies of scale and redeem theirfinancial position in the face of downturn or decline in the product life cycle should diversify its product lines to better meet customers' demands, as well as to achieve profitability and expansion as well as increase performance, since diversified organizations were found toperform better than the undiversified entities. Furthermore, organizations should identify their rare and inimitable capabilities in order to achieve economies of scale and outsmart competitors. Finally, R\&Dcentres should be developed to achieve the most cost-effective channelling of resources, the identification of opportunities as they arise in the business environment, as well as to select other strategic options in the most effective way.

\section{References}

1. Adamu, N., Zubairu. I.K., Ibrahim, Y., M. \& Ibrahim, A. M. (2011). Evaluating the impact of product diversification on financial performance of selected Nigerian construction firms. Journal of Construction in Developing Countries, 1 (2), 91-114.

2. Ajay, R., \& Madhumathi, R. (2012). Diversification strategy and its influence on capital structure decisions of manufacturing organizations in India. International Journal of Social Sciences and Humanity, 2 (25), 421-426.

3. Akewushola, R. (2015). Performance effectiveness and related product marketing diversification strategy in Nigerian companies: Information and communication technology as virile tool. Journal of policy and Development Studies, 9 (2), 211-218.

4. Akkermans, A.C.A. (2010). The diversification-performance relationship. Modification during financial crisis? Conceptual and empirical understanding. Tilburg University. Retrieved on February 25, 2018 from arno.uvt.nl/show.cgi?fid=112888

5. Akpinar, O. \& Yigit, I (2016). The relationship between diversification strategy and firm performance in developed and emerging economy contexts: evidence from Turkey, Italy and Netherlands. 13th International Scientific Conference on Economic and Social Development, Barcelona, 583-592

6. Alli, S., Hashmi, S.H., \&Mehmood, T. (2016). Corporate diversification and firm performance: An inverted u-shaped hypothesis. International Journal of Organizational Leadership, 20 (5), 381-398.

7. Asrarhaghighi, E., Rahman, E.A., Sambasivan, M., \& Mohamed, Z.A. (2013). Diversification strategy and performance: Results, measures and sampling design. European Journal of Business and Management, 2 (3), 12-18. 
8. Ayeni, (2013). The effects of economic diversification on the development of tourism in Nigeria. American Journal of Tourism Management, 2 (1), 15-21

9. Castaldi, C., \& Giarratana, M.S. (2018). Diversification strategy, branding and performance of professional service firm. Journal of Service Research, 21 (3), 353-354.

10. Dosi, G., \& Teece, D.J. (1993). Organisational competences and the boundaries of the organization market and organization. Journal of Management, 2 (23), 21-60.

11. Emel, Y.,\& Yildirim, B.O. (2016). Industrial diversification and performance in an emerging market. Panoeconomicus, 63 (4), 441-454.

12. Gul, S. (2011). The effects of integration strategies on organization's performance: An empirical studies on Danish manufacturing organizations. Aarhus School of Business, Aarhus University.

13. Haim, H. (2015). Significance of studying product diversification, geographic diversification, and their interaction impacts for Malaysian companies: a literature review. Asian Social Sciences Journal, 11 (10), 238-250.

14. Harrigan, K.R. (2012). The synergy limitation paradox. Columbia Business School Research Paper, 15 (15), 69-87

15. Hasby, H., Buyung, S., \& Hasbudin, S. (2017). The effect of organization size and diversification on capital structure and organization value (study in manufacturing sector in Indonesia Stock Exchange). The International Journal of Engineering and Science, 6 (6), 50-61.

16. Hashai, N. (2015). Within industry diversification and firm performance-An S-shaped hypothesis. Strategic Management Journal, 36 (9), 1378-1400.

17. Haug, J., \& Ultich, P. (2013). Diversification and competitive advantage: A risk-based explanation. Academy of Management Annual Meeting Proceedings, 2013 (1), 13418-13418

18. Ivan, P., \& Maja, P. (2010). Effects of corporate diversification onits performance: the case of Croatian non-life insurance industry. Ekon. Misao I Praksa Dbk. God, 19 (1), 49-66

19. Jasper V.D.B. (2016). Corporate diversification and firm performance: The effect of global financial crisis on diversification in India. A dissertation submitted to University of Groningen.

20. Junior, J. N., \& Funchai, B. (2013). The effect of corporate diversification on the capital structure of Brazilian organizations. Revisca Contabilidade \& Financas, 24 (62), 154-161.

21. Karimi, D.G. (2013). Relationship between investment portfolio choice and profitability of investment companieslisted in the Nairobi securities exchange. Unpublished MBA thesis, Kenyatta University.

22. Krivokapic, R., Nladimir, V., \& Stojic, D. (2017). Effects of corporate diversification on organization's performance: Evidence from the Serbian insurance industry. Economic Research Journals, 30 (1), 1224-1236.

23. LaRocca, M., \& Stagliano, R. (2012). Unrelated diversification and organization performance: 1980-2007 evidence from Italy. Australian Accounting, Business and Finance Journal, 6 (1), 75-82.

24. Makau, M.M., \& Ambrose, J. (2018). The impact of portfolio diversification on financial performance of investment firms listed in Nairobi Security Exchange Commission, Kenya: Empirical review. International Journal of Management and Commerce Innovation, 5 (2), 177-187. 
25. Manyuru, A., Wachira, M., \& Amata, E. (2017). The impact of corporate diversification on organization value in Kenya. African Journal of Business Management, 11 (11), 241-249.

26. Martinez-Campillo, A. (2016). The benefits of related and unrelated diversification strategies in the Spanish context: What is the difference that executive leadership style can make? Leadership-Sage, 12 (1), 86-109.

27. Mohindru, A., \& Chander, S. (2010). Diversification strategy and corporate performancein India: an empirical investigation. Asia-Pacific Journal of Management Research and Innovation, 6 (3), 124-137.

28. Nasiru, A., Ibrahim, K.Z., Yahya, M.I., \& Aliu, M.I. (2011). Evaluating the impact of product diversification on financial performance. Journal of Economics and Sustainable Development, 16 (2), 91-114.

29. Nyaingiri, S., \& Ogollah, K. (2015). Influence of unrelated diversification strategy on corporate performance: A study of Sameer group in Kenya. Journal of Business and Management, 17 (4), 78-83.

30. Oh, C.H., Sohl, T., \& Rugman, A.M. (2014). Regional and product diversification and the performance of retail multimedia, discussion paper. Henley discussion paper series. Viewed on December 5, 2018, from www.henley.ac.uk/html

31. Oladele, O.P. (2012). Product diversification and performance of manufacturing organizations in Nigeria. European Journal of Business Management, 10 (1), 226-233.

32. Oyedijo, A. (2012). Effects of productmarket diversification strategy oncorporate financial performance and growth: Anempirical study of some companies in Nigeria. Global Advanced Research Journal of Management and Business Studies, 1 (1), 061-069

33. Pandya, A.M. \& Rao, N.V. (2011). Diversification and firmperformance: An empirical evaluation. Journal of Financialand Strategic Decisions, 11 (2), 67-81.

34. Qureshi, M.Z., Akhar, W., \& Imdadullah, M. (2012). Does diversification affect capital structure and profitability in Pakistan? Asian social sciences, 8 (4), 30-42.

35. Rishi, M., Rudra, R., \& Vinay, N. (2014). Interactive effect of diversification strategy on capital structure and corporate performance: An analytical evaluation. Global Journal of Management and Business Research, 14 (4c), 1-9

36. Rowe, F. (2014). What literature review is not: Diversity, boundaries and recommendation? European Journal of Information System, 23 (3), 54-90.

37. Sahu, S.K. (2017). Firm performance and diversification: An empirical investigation of chemical sector in India. International Journal of Sustainable Economy, 9 (1), 56-71.

38. Santarelli, E., \& Tran, H. (2015). Diversification strategies and firm performance in Vietnam. Economics of Transition, 24 (1), 31-68.

39. Schommer, M., Richter, A. \& Karna, A. (2019). Does the diversification firm performance relationship change over time? A meta analytic review. Journal of Management Studies, 56 (1), 91-133.

40. Sindhu, M., Haz, E., Ali, S., \& Ali, M. (2014). Impact of diversification on the organizations performance: An evidence from Pakistan. European Journal of Business Management, 6 (4), 106-111. 
41. Shyu, J., \& Chen, L.Y. (2009). Diversification, performance and the corporate life cycle states. Emerging Markets Finance and Trade, 20 (45), 57-68.

42. Su, W., \& Tsang, E.W.K. (2013). Product diversification and financial performance: the moderating role of secondary shareholders. Academy of Management Journal, 3 (2), 1128-1148.

43. Sulaimon, A. A., Ogunkoya, O. A., Lasisi, J. O., \& Shobayo, P. B. (2015). The impact of marketing capability and diversification strategy on performance. Journal of Marketing and Consumer Research, 20 (13), 50-59

44. Thompson, A.A., Stickland, A. J., \& Gamble, J., (2010). Crafting and executing strategy: The quest for competitive advantage- Concepts and cases. Boston: McGraw-Hill/Irwin.

45. Ugwuanyi, G.O., \& Ugwu, J.N., (2012). The effect of corporate diversification on the profitability of financial service sector in Nigeria. World Academy of Science, Engineering and Technology, 6 (7), 1729-1732.

46. Valis-Boas, R., \& Suarez-Gonzalez, I. (2015). Internationalisation and organization performance: the S-curve hypothesis under Eurozone context. NuevasTendenciasendireccion De empresas, 15 (7), 1-20.

47. Mawdsley, J. (2019). Considering a diversification strategy? Follow insights from HEC. Knowledge Article, 1-4

48. Xaxx, J. (2017). The disadvantage of diversified business. Retrieved on October 30, 2017 from www.chronbusiness.chron.com

49. Yigit, I., \& Tur, S. (2012) Relationship between diversification strategy, application and organisational performance according to Heifindahl index criteria. Procedia. Journal of Social and Behavioural Sciences, 3 (6), 118-127.

50. Zheng-feng, G., \& Lingyan, C. (2012). An analysis of the degree of diversification and organization's performance. International Journal of Businesses and Finance research, 6 (2), 53-58.

\section{Contact Information}

Moruff Sanjo Oladimeji (Ph.D.)

Department of Business Administration

Faculty of Administration \& Management Sciences

Olabisi Onabanjo University

Nigeria

Email:moruff.oladimeji@oonagoiwoye.edu.ng

Udosen Itohowo

Postgraduate school

Babcock. University, Ilisan- Remo

Ogun State

Nigeria 